\title{
A Study on ESP Chinese-English Translating Practice Based on the Translation Memetics*
}

\author{
DING Zi-hua \\ Jiangsu Maritime Institute, Jiangsu, China
}

\begin{abstract}
"Memes" translation theory has been applied in translation practice, especially in the field of ESP (English for Specific Purposes) translation. In view of this, based on the relevant "memes" translation theory and the professional module positioning expressed by ESP, this article analyzes ESP language memes analysis and illustrates some related translation strategies employed in ESP Chinese-English translating practice properly, such as direct translation and indirect translation, semantic translation and communicative translation, foreignizing translation and domesticating translation, etc.
\end{abstract}

Keywords: translation practice, memes, ESP

\section{Introduction}

Language is a symbol system which is unique to humans and develops with the development of the society. However, due to the difference of the regions, ages, and social environments, people have different ways of thinking, which result in various differences in language system to be difficult to communicate directly with each other. Chinese emphasizes people-oriented basis "people are naturally corresponding", but English emphasizes the object, "the person corresponding to god", such as “房奴”, which must be translated into "mortgage houses/slave" but cannot be directly translated into "house slave". In addition, because of deepening the international cultural exchange, there are a lot of integrations in different cultures, such as “中国大妈” often directly translated into "Chinese Dama" in foreign newspapers.

ESP (English for Specific Purposes) is one branch of language which is associated with a particular subject, professional and activities, and vocabularies, grammar, discourse, and semantics in ESP are centered on the corresponding professional module. ESP is the organic combination of language skills and professional knowledge which has its own various vocabularies, syntax, and structure models and every major has its own corresponding professional English, therefore, it is particularly important that accurately expressing the meaning of one professional language into another language, namely ESP translation practice.

\footnotetext{
* Foundation Item: Key Project of Jiangsu province "the Twelfth Five-year" Plan for Education-science: "The Study on Constructing the Double-qualified ESP Teaching-team in Higher Vocational Colleges by School-enterprises Interaction" (Project No. B-b/2011/03/021).

DING Zi-hua, associating professor, M.A., Navigational College, Jiangsu Maritime Institute, Jiangsu, China.
} 


\section{"Memes" Translation Theory}

As a medium for people to express their thoughts, language is a kind of unified coding decoding standard voice signal designed to communicate. Because of being formed and developed in a state of relatively independent, every language has its unique way of expression. In order to achieve mutual understanding, the exchange between different languages must consider the special contents and transform the language differences with the help of a specific "parameter". In 1976, Richard Dawkins (1976), one British scholar, would compare the process of cultural inheritance with the evolution rules of biological. "Memes", therefore, as a cultural heritage factor, exists in the process of cultural transmission selection, adaptation, and mutation, Therefore, "memes", as a cultural inheritance factor, has some selections, adaptations, and variations in the process of cultural transmission. Chesterman (1996b) and Vermeer Hans J (1997) were the earliest people introducing memetics into the studies of translation theory and made the relevant translation practice and theory as translation memes which tries to use genetic model to interpret and deconstruct the universal relationships between languages and cultures by certain parameters.

\section{Language Isomorphs}

Language isomorphism is essentially a mapping, by which can represent another system structure. There are many Chinese and foreign linguisticians, such as Eugene A. Nida, Even-Zohar (1972), Newmark, Chesterman (1977), etc., who demonstrated all languages have homogeneous characteristics by studying phonetics, phonology, syntax, semantics, pragmatics, and philosophy of language, especially Richard Montague (1970), who is an American logician, introduced Yuan-mathematical approach into the study of the natural language lexical and syntactic, semantic, and pragmatic and established a complete set of the connotation of logic, which is called Montague grammar whose significance lies in the isomorphism theory of language form and semantics, which attracts widespread concern in the theory of semantic field and computational linguistic. Because of having isomorphic nature, it can be understood and translated. In the process of translation, isomorphism is trans-coded by the corresponding parameters.

\section{Language Parameter}

Language isomorphism shows that different languages can be transformed, but this transformation must depend on the technical aspect, namely the reasonable structure of the target language and source language analyzing and the correct processing to achieve successful transformation, and the factors necessary to analyze rationally and correctly, namely "language parameters". These parameters play important roles in translating, including context (V1), common sense (V2) and language knowledge (V3) and so on, that $\mathrm{S}=\mathrm{V} 1+\mathrm{V} 2, \mathrm{~V} 3+\ldots$, which cause some differences in phonetics, semantics, syntax, pragmatics, etc. The same language expressing in a different context has completely different meanings, such as "Now he is on the bridge", which can be usually translated into Chinese “现在他在大桥上”, but on ship it is only translated into “现在他在驾驶台”.

\section{Linguistic Trans-coding}

Different languages, forming and developing in the relatively independent environments, have their own special expressions. Based on homogeneity of language, these expressions can transform by the language parameters in some way, which is named "language transfer-code" and all translations are the concrete practice of the trans-coding and reflection. Eugene Nida, the famous American translation theorist, in The Theory and 
Practice of Translation (1974) pointed out that translation must undergo the analysis of the language translation, transferring, processing and restructuring and so on, and trans-coding in language, culture, and background knowledge needs to express in the external form of language. In trans-coding, you may meet a lot of problems which are solved by the related language parameters of and various language means, such as part of speech of change, increase or decrease in word, omit, long sentence processing, idioms, onomatopoeia, domestication, and foreignization. At present, due to the professionalism of the ESP translating practice, many scholars adopt the strategies of translation in memetics angle in the process of trans-coding, such as literal translation and free translation, semantic translation and communicative translation, and foreignizing translation and domesticating.

\section{ESP Translation Practice Analysis}

Tom Hutchinson and Alan Waters (1987) pointed out in English for Specific Purposes "The principal idea behind the skills-centered approach is that underlying all language use there are common reasoning and interpreting processes which, regardless of the surface forms, enable us to extract meaning from discourse" ( $\mathrm{p}$. 13). Therefore, the ESP translating strategies should be based on professional module contents and structure of sentences or passages and combined with relevant translation theories.

\section{Determining the Professional Module}

The purpose of ESP is to meet specific needs which take some methodologies and activities of the discipline it serves and focus on grammar, lexis, register, study skills, discourse, and genre. Before ESP translation, position professional module first understands what is the professional scene and we can translate accurately and reflect the performance of professional content correctly.

For example: I am entering the logbook.

Correct: “我正在填写航海日志”

Wrong: “我进入日志” or “我进入圆木本”

Another example: Can I ever forget that day when I first I came to my husband's people? I had the one great consolation of a bride, my parents had not sent me away empty-handed. The procession was almost a li in length and I watched with a smelling heart the many tens of coolies carrying my household goods.

If you want to translate this paragraph correctly, first you must accurately locate this text which is a letter that one wife wrote to her husband in the late 18th century and the expression "one great consolation of a bride" means "The bride has a lot of dowry".

So the correct translation is “我不能忘记我第一次嫁到夫家的情景, 我的父母并没有让我两手空空嫁 到夫家而是给我配了很多嫁妆, 婚礼的的队伍大概有一里长, 我志忈的看着几个苦力抬着我的嫁妆”.

\section{Analyzing Language Memes}

HE Zi-ran (2005), one famous Chinese translation theorist, pointed out that language memes refers to the language cultural genes and each culture passes down from generation to generation by their own cultural genes, and communicates between different cultures by translation memes copy and spread. Because ESP has its unique vocabulary, context, and linguistic structure model and has some differences from regular English, in analyzing ESP language memes, the translator should understand the relevant language parameters by using relevant theories, such as combining it with the grammar and semantic structure and context and pragmatic analysis to 
achieve the group semantics to unit. The first step is to understand the source language, because only correctly understanding the language memes of the source language, the translator can be able to understand the source language to introduce and understand the language to express the each professional scene exactly. Usually ESP should be supplemented by item $\mathrm{S}(\mathrm{S}=\mathrm{V} 1+\mathrm{V} 2, \mathrm{~V} 3+\ldots)$ and the scenario related defect information.

For example: For the purpose of these Rules, except where the context otherwise requires.

除其他条文另有解释外, 在本规则中要求。

The language is simple but includes much information, which concludes context (V1) which introduces the purpose of the law, professional knowledge (V2), and the use of the laws and regulations and relevant language information (V3). Parameter determines the translating strategy, so only analyzing the language memes and understanding the relevant parameters accurately, it can guide the translation practice effectively.

Another example: International countertrade is a practice whereby a supplier commits contractually-as a condition of sale-to reciprocate and undertake certain specified commercial initiatives that compensate and benefit the buyer.

国际对等贸易实践是指供应商合同承诺互惠货物, 作为销售条件则是确保以约定的商业利润补偿 买方。

In this sentence, the translator should understand the language memes of the international trade practice in this module and the relevant memes. Such as international countertrade (国际对等贸易), practice (做法/惯例/ 实践), reciprocate (货物互换), undertake certain specified commercial initiatives (确保约定的商业盈利/利润) (This is the key to this sentence to understand), specified (合同指明的/规定的), and compensate and benefit (补 偿并受益于).

\section{Translation Strategies Employing}

Eugene A. Nida (2004) thought that translation is using the most appropriate and most natural equivalent language to represent the source language information. The purpose of translation is not only the equivalence of the sense of the vocabularies, but also the cultural equivalence of the meaning, style, culture, society, etc. When translated, text should not be required the one-to-one correspondence, but needs to achieve functional equivalence between the two languages. Therefore, taking appropriate translation strategies should be according to its own characteristics and the corresponding translation norms.

\section{Translation Specification Definition}

Translation specification, namely the translation criteria or translation principles, must follow the specification in the translation practice. With the development of translation theory and translation practice, more and more linguists study the translation norms. Such as Gideon Toury, one Israel scholar, inherited and developed the theory of multiple systems of another famous Israel scholar Even Zohar (1972), which is the first systematically descriptive study of translation norms. Toury published some books, such as In Search of a Theory of Translation in 1980 and Descriptive Translation Studies and Beyond in 1995 and so on. Especially in Descriptive Translation Studies and Beyond, he established the theory of translation norms, which are descriptive translation research, case study, and translation criteria.

Eugene A. Nida introduced the information theory and semiotics theory into the translation theory, put forward the translation criteria "dynamic equivalence, namely functional equivalence", and emphasized that 
translation must be closest natural equivalence of the source language information and be the equivalence and the fusion of vocabularies, syntax, and discourse and stylistic.

Chesterman (1993), a famous American scholar, thought that once a certain translation concept factor occupies the dominant position, it will become translation norms. Based on Darwin's memes concept of evolution theory, he tried to use memes theory to explain people's understanding of translation from different angles in different historical periods. Graph theory had a big influence on him, but he studied norms influence on translation practice further and he emphasized initial specifications and operation specifications more and divided them into expectancy norms and professional norms.

\section{Translation Strategies Employing}

Translation practice includes the correct understanding, full expression, and careful calibration, namely the specific process of the source language information. By analyzing and comparing the structure, parameters adopt appropriate strategy of source language and carry on the reasonable trans-coding, so they can achieve the target language. Therefore, the translator should be familiar with the related literary style consciousness and professional knowledge, that is to say, the translator should know the material of the source language context, especially when the translator meets certain words or sentences which cannot be expressed in the target language accurately, such as jargon, plural, fold with synonyms, and words collocation of words; and then by the text and professional module and choosing the right meaning, the translator take certain translation strategies.

This article only discusses translation strategies which many Chinese scholars have studied in recent years, such as literal translation and free translation, semantic translation and communicative translation, foreignizing translation and domesticating, and how to grasp and use properly according to many other factors which meet the actual demand for translation practice and context, stylistic, audience and so on.

Literal translation and free translation. Literal translation refers to translate word for word by the original one to one, which can keep the content of the original and the original form. It can faithfully express the original meaning and reflect the original style in the translation, but not mechanical translation, which is mainly used in translating science and technology information, trademark translation, or the foreign language teaching.

For example: Oreo is one chocolate cookie produced by Kraft Foods Company in the United States. It can be translated directly into “奥利奥是由美国卡夫食品公司生产的巧克力曲奇饼”.

Anther example: If there is sufficient sea-room, alteration of course alone may be the most effective action to avoid a close-quarters situation provided that it is made in good time, is substantial and does not result in another close-quarters situation. This is a clause in International Regulation for Preventing Collision at Sea. It can also be translated directly.

如有足够的水域, 则单用转向可能是避免紧迫局面的最有效行动, 倘若这种行动是及时的、大幅度 的, 并且不致造成另一紧迫局面。

But due to the differences between Chinese culture and Western culture and logical thoughts, literal translation also has some limitations. If only using literal translation, it can make the audience to misunderstand, even mistranslate, therefore, sometimes free translation is required.

Such as How do you deal with your sanitary water (Maritime English), if you use literal translation, it can be mistranslated into “你怎样处理卫生水”, but the correct is “你怎样处理生活污水”. 
A lot of nouns express different meanings by the single and plural form, such as government (政府; 政体) $\rightarrow$ governments (政权; 政府行为; 可转让政府证券); achievement (成就) $\rightarrow$ achievements (成果, 业绩); effect (效果, 作用) $\rightarrow$ effects (财物, 动产); liability (责任, 义务) $\rightarrow$ liabilities (债务, 负债) and so on.

Even the same word in different context means not the same, such as proceed, as a verb, means “前进, 行 进”, but as a noun, especially in plural form means “收入, 收益” (engaged in some activity or sell the property) or in business means “汇款” and “货款”. For example, net proceeds means “净售得款”; “The proceeds of the concert went to charity” means “音乐会的收入交给慈善机构”; “The estate agent required 2\% commission on the proceeds from the sale of the house” means “房地产经纪人要求收取出售房子实得款项的 $2 \%$ 作为佣金” and so on.

Semantic translation and communicative translation. Semantic translation and communicative translation are two translation approaches presented by Peter Newmark (1977). Based on the original contents and the background of source the language culture, it explains the meaning of the original and help understand the meaning of a text for the target language readers. For example, a lot of cargo is usually mistranslated into “许 多货”, but its correct translation is “一票货”; lot labels should be translated into “货票标签”. Therefore, Newmark thought that the purpose of semantic translation is to reproduce accurately what is expressed by the author on the basis of the target language structure and semantics

The other examples, "foreign smell" in the sentence "Strong smelling cargo should be stowed away from the cargo absorbing foreign smell" means “异味”; “the actual broken stowage" in "The actual amount of cargo loaded depends upon the actual broken stowage” means “实际亏舱”; “The additional cargo" in "The additional cargo is to be loaded on board our ship" means “加载货”; “ballast", “trim”, and "stability” in "Ballast means heavy material strategically placed on a ship to improve its trim or stability", all of which are nautical terms meaning “压载”, “纵倾、首尾吃水差”, and “稳性” respectively. In translating these sentences, the translator should understand the ballasting operation in cargo transportation.

It is important for Semantic understanding to understand the long sentences or paragraphs, which used to explain the major professional module.

For example, STOWAGE INSTRUCTIONS are specific instructions given by the consignor in a letter or on a shipping line or freight forwarder's pre-printed form regarding how or where a shipment should be stowed during transport. For example, a shipper may require that the shipment be placed below deck and amidships for greater protection from the elements and movement of the ship.

STOWAGE INSTRUCTIONS is a term of the international carriage of goods by sea which means “配载/积 载指令”. Therefore this paragraph can be translated into “配载/积载指令是发货人以信件或以航运公司或其 代理以打印格式给出的在运输途中关于在哪里如何正确装载货物的具体指令。如: 托运人可以要求其货 物在甲板下即舱内装载或中舱装载以更好的保护货物免受恶劣天气及船舶摇摆运动所造成的损害”.

However, this strategy was complicated and cumbersome and the translation is too detailed. Because it is too mechanically understanding the language structure and the vocabulary, so sometimes it is also mistranslated.

Based on the original and the background of the target language, communicative translation focuses on the target language and tries to help the reader to overcome the difficulties in the professional reading or communication, which only provides information for the reader, and the translation is pure, smooth, and easy to 
understand, which is observed by the translation norms. Such as "Ease the helm" in ship-handling operations means “回舵” and so on.

Foreignizing translation and domesticating translation. In ESP translating practice, it is so important for the translator to know how to deal with some professional and very abstract theories that can make the audience easily understand. Lawrence Venuti (1995), a famous American scholar, put forward the theory of foreignizing translation and domesticating translation in the process of translation in The Translator's Invisibility A History of Translation in 1995.

Domestication is the strategy of making text closely conform to the culture of the language being translated to, which may involve the loss of information from the source text.

For example, "There is much wailing in the courtyards. The gardener and the bearer and watchman are having bound their feet small daughters. The saying, 'For every pair of golden lilies there is a kang of tears"'. If translating this passage, the translator should understand woman Foot-binding in Chinese society before the early 19th century and then deal it with domestication translation so it can be translated into “由于园艺工人、轿夫及 更夫正在给他们的小女儿裹脚，院子里有许多哭声，真是“小脚金莲一双，痛苦眼泪一缸”, which can enhance the translation of appreciating and improve the practicability of the translation.

Another example, “There is a tendency for an organization of this type to be rather romantic; this place isn't romantic - it actually makes money. He is impressed equally by the open information policy, which circulates details of all meetings to employees, and the rapid growth".

It can be translated into “这种公司常有夸大事实的倾向，但这家公司不是这样一相反它是盈利的。公 司的信息公开政策，即所有公司会议的细节都传达给雇员，及公司快速发展的态势同样给他以很深的印 象”.

However, sometimes the source language, especially in certain words and terms, taking domestication translation is unable to accurately express and hard to understand; at this point, the translator should accept the source language expression, literally the alienation and original text by the characteristics of the source language,

For example, black horse means “黑马”, cumshaw means “小费; 赠品”, crocodile tears means “鳄鱼的 眼泪”, nose suspended motor means “鼻挂式电机”, web-sex means “网络色情” and so on.

\section{Conclusion}

As a kind of translation theory, theory of memes has opened up a different perspective for ESP's translation, therefore, in ESP translating, at first the translator should understand and pay attention to the guidance of translation theory, and by which carefully analyze of the language structure itself, determine the ESP module correctly, and then make full use of related language parameter to achieve reasonable linguistic trans-coding. At the same time, use it in translating, analyze the source language and target language cultural background multi-angle and comprehensively, and use relevant translation strategies properly to improve the accuracy of the ESP translation.

\section{References}

Blackmore, S. (1999). The meme machine. Oxford: OUP (Oxford University Press).

Chesterman, A. (1993). From "Is" to "Ought" translation laws. Norms and Strategies Target, 5, 1-20. 
Chesterman, A. (1995). The successful translator the evolution of homo transferens. Perspective: Studies in Translatology, 2 , 253-270.

Chesterman, A. (1996a). Teaching translation theory: The significance of memes (pp. 63-71). Andrew Amsterdam: Benjamins.

Chesterman, A. (1996b). Teaching translation theory: The significance of memes. In C. Dollerup and V. Appel (Eds.), Teaching translation and interpreting. Amsterdam: Benjamins.

Chesterman, A. (1997). Memes of translation. Amsterdam: John Benjamins.

Elizabeth, C. (2010). My lady of the Chinese courtyard. USA: Kessinger Publishing.

Eugene, A. N., \& Charles, T. R. (2004). The theory and practice of translation. Shanghai: Shanghai Foreign Language Education Press.

Even-Zohar. (1972). An outline of a theory of the literary text (Ha-Sifrut III, pp. 427-446). Retrieved from https://en.wikipedia.org/wiki/Itamar_Even-Zohar

HE, Z. R. (2005). Memes in language. Linguistic Sciences, 6, 54-64.

Hutchinson, T., \& Waters, A. (1987). English for specific purposes. England: Cambridge University Press.

Newmark, P. (1977). A textbook of translation. Retrieved from http://www.doc88.com/p-890573293935.html

Richard, D. (1976). The selfish gene. Retrieved from https://en.wikipedia.org/wiki/The_Selfish_Gene

Richard, M. (1970). Universal grammar. Retrieved from https://en.wikipedia.org/wiki/Montague_grammar

Venuti, L. (1995). The translator's invisibility a history of translation. Shanghai Foreign Language Education Press, 50(1), 47-49.

ZHAN, X. N. (1986). Montague grammar assessment. Foreign Languages and Their Teaching, 4, 10-13. 